\title{
Examining Relationships Between Organic Leadership And Corporate Sustainability: A Proposed Model
}

Sooksan Kantabutra, Mahidol University, Thailand Suparak Suriyankietkaew, Mahidol University, Thailand

\begin{abstract}
Much of the leadership literature indicates that organizations adopting the Organic leadership paradigm tend to respond to the environmental change more effectively than those adopting other leadership paradigms, therefore more sustainable. However, few published studies, if any, have specifically investigated the assumed relationship between Organic leadership and sustainability performance. Derived from the literature, a model expressing the relationships between Organic leadership characteristics and sustainability performance outcomes is proposed. The broad proposition is the more organizations adopting the Organic leadership characteristics, the better the sustainability performance outcomes. In this paper, characteristics of Organic leadership such as shared vision and values, self-leading, self-managing, mutual sense-making are independent variables, while sustainability performance outcomes such as financial results, longterm shareholder value, customer satisfaction, brand and reputation are dependent variables. Relevant hypotheses and directions for testing them are also discussed.
\end{abstract}

Keywords: Leadership Paradigm; Organic Leadership; Shared Leadership; Corporate Sustainability Performance

\section{INTRODUCTION}

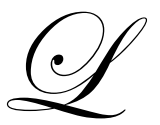

eadership studies evolve as organizational contexts change. Leading complex, global organizations where innovation and rapid technological advancement are inevitably has become an increasing challenge for modern organizations (Marion \& Uhl-Bien, 2007; Schneider \& Somers, 2006; Uhl-Bien, Marion, \& McKelvey, 2007). Advance information technology and fast-changing competitive business environment in the knowledge economy, today's organizations are operating in even more complexity and uncertainty than in the past. Leadership theories that fit the 21 th-century dynamic environmental context need to take into account factors and many related parties which interact with leaders and organizations (Avery, 2004). Traditional leadership paradigms with reliance on one individual leader limits organizational effectiveness in dealing with complexities (Day, Gronn, \& Salas, 2004) and may expose any organization to a certain degree of risk (Conger \& Kanungo, 1998). As we are moving toward the knowledge era, traditional leadership theories and paradigms, including classical, transactional and visionary, with a heavy focus on a single-dominant leader thus cannot survive such challenges and is no longer appropriate (Manville \& Ober, 2003; Pearce \& Manz, 2005; Uhl-Bien et al., 2007). The limitations of the traditional leadership paradigms and the popular visionary leadership have led scholars to search for alternative leadership paradigm that can broaden and transcend leadership concepts into the next level.

Contradicting with the traditional leadership paradigms, Organic leadership paradigm (Avery, 2004) has shifted the notions of traditional leadership paradigms. New leadership models gear toward a more relational process and a shared or distributed phenomenon, which can occur at different levels depending on social interactions and networks of influence (Fletcher \& Kaufer, 2003). Today's organization emphasizing on lateral relationship across functions, business units, and geographic regions are gearing toward alliances, outsourcing and teams (Raelin, 2005; Snow \& Miles, 1992). Leadership is often shared across the various partners or members making it difficult for a single individual of one entity to truly lead the alliance or network (Pearce, Conger \& Locke, 2008). 
In recent years, leadership researches focusing on non-leader orientation of shared, distributed or collective forms in team-base context have gained much interest. DeChurch et al. (2010)'s review of the past 25 years of leadership research assert that there is a growing interest in understanding the effect of growing collective forms (e.g. team, units or organizations) of the leadership. Based on the literature, organizations operating under the Organic leadership tend to respond to the environmental change more effectively than those adopting the visionary leadership. As organizations of the 21th-century are operating under complexity in dynamic context, Organic leadership becomes imperative and vital for corporate sustainability.

Understanding effects of leadership on performance is also essential to measure organizational viability toward corporate sustainability. According to Jing \& Avery (2008), researchers (Judge, Heller \& Mount, 2002; Judge \& Piccolo, 2004; McGrath \& MacMillan, 2000; Meyer \& Heppard, 2000; Purcell et al., 2004; Yukl, 2002) signify the importance of a study on strategic role of leadership and evaluation of how to utilize leadership paradigms and employ leadership behavior to improve organizational performance. According to Jing \& Avery (2008), future studies need to broaden the examination of leadership-performance relationship to include other leadership paradigm such as the Organic paradigm. The understanding of Organic leadership and sustainability performance outcomes still requires scrutiny. Hence, an identified gap for the present study is an uncovered relationship between Organic leadership's characteristics and sustainability performance outcomes. To further extent our understanding on the relationship, we propose a broad proposition that Organic organizations are likely to produce better sustainability performance outcomes, including financial outcomes, customer satisfaction, brand and reputation, shareholder value, long-term stakeholder value than those organizations adopting a traditional leadership paradigm. Relevant literature is reviewed, followed by a structural model, resulting hypotheses and some directions to test them.

\section{ORGANIC LEADERSHIP}

After the turn of the twenty-first century, contemporary leadership concepts and theories are gearing toward Organic leadership. The studies of leadership have been revolutionized from dependence over one single leader to a non-leader focus paradigm to reflect changes in organizations and their environment. The emergence of Organic leadership has been a phenomenon in the last decade. Based on a review of 353 articles in The Leadership Quarterly's second decade of 2000-2009 (Gardner et al., 2010), several leadership theories and concepts emerge to support the significant movement toward the new direction of leadership studies. Distributed leadership (Brown \& Gioia, 2002; Chambers, Drydales, \& Hughes, 2010; Gronn, 2002; Mehra et al., 2006), shared leadership (Arnone \& Stumpf, 2010; Avolio et al., 1996; Day et al., 2004, 2006; Ensley \& Pearce, 2001; Ensley, Hmieleski \& Pearce, 2006; Hiller, Day \& Vance, 2006; Hooker, \& Csikezentmihalyai, 2003; Pearce \& Sims, 2002; Pearce \& Conger, 2003; Pearce \& Manz, 2005; Pearce, Manz, \& Sims, 2009; Shamir \& Lapidot, 2003), team leadership (Burke et al., 2006; Day et al., 2004, 2006; Morgeson, DeRue \& Karam, 2010; Tagger \& Ellis, 2007; Zaccaro, Rittman \& Marks, 2001), collective leadership (Avolio, Walumbwa, \& Weber, 2009; Carson, Tesluk \& Marrone, 2007; Crevani, Lindgren \& Packendorff, 2009; Friedrich et al., 2009; Hauschildt \& Kirchmann, 2001; Uhl-Bien et al., 2007), empowering leadership (Arnold et al., 2000; Ensley et al., 2006; Manz, Pearce, \& Sims, 2009; Kirkman, \& Rosen, 1999; Srivastava, Bartol \& Locke, 2006; Vecchio, Justin \& Pearce, 2010) and leaderful practice (Raelin, 2005, 2006) are emergent leadership concepts that possess properties of the Organic leadership. They share similar concepts and characteristics that move away from leader-centric, less command and control from the top, but rather focusing on collective, team works of multiple members of organization to achieve common goals. In the literature, these terms are used interchangeably since their focuses are common, with some varying degrees. Table 1 illustrates diverse leadership notions underlying the Organic leadership paradigm and their links to different performance outcomes. 


\section{Table 1: Summary of leadership notions underlying the Organic Leadership paradigm and their links to performance outcomes}

\begin{tabular}{|c|c|c|c|c|}
\hline $\begin{array}{l}\text { Relevant } \\
\text { notions of } \\
\text { Organic } \\
\text { leadership }\end{array}$ & $\begin{array}{l}\text { Influential } \\
\text { researchers }\end{array}$ & Tenet & Reference & Finding \\
\hline \multirow[t]{3}{*}{$\begin{array}{l}\text { Distributed } \\
\text { leadership }\end{array}$} & \multirow{3}{*}{$\begin{array}{l}\text { Brown \& Gioia, } \\
\text { 2002; Chambers } \\
\text { etal., 2010; } \\
\text { Gronn, 2002, } \\
\text { 2005; Mehra et } \\
\text { al, } 2006\end{array}$} & \multirow{3}{*}{$\begin{array}{l}\text { An alternative leadership approach with } \\
\text { non-leader centric focus toward self- } \\
\text { leading. It centers on the dispersed } \\
\text { leadership among organizational } \\
\text { members. Leadership can be distributed } \\
\text { across members through active cultivation } \\
\text { and development of leadership abilities } \\
\text { within all members. }\end{array}$} & Gronn (2002) & $\begin{array}{l}\text { Distributed leadership can promote organizational } \\
\text { capability and performance. }\end{array}$ \\
\hline & & & Carmeli \& Schaubroeck (2006) & $\begin{array}{l}\text { Distributed leadership among a top management } \\
\text { team is related to positive organizational outcomes. }\end{array}$ \\
\hline & & & Mehra et al.(2006) & $\begin{array}{l}\text { Distributed leadership is significantly related to } \\
\text { financial performance (higher sales). }\end{array}$ \\
\hline \multirow[t]{5}{*}{$\begin{array}{l}\text { Shared } \\
\text { leadership }\end{array}$} & \multirow{5}{*}{$\begin{array}{l}\text { Arnone \& } \\
\text { Stumpf, 2010; } \\
\text { Avolio etal., } \\
\text { 1996; Day et al., } \\
\text { 2004; Ensley et } \\
\text { al.,2003, 2006; } \\
\text { Hiller et al., } \\
\text { 2006; Pearce \& } \\
\text { Sims, 2002; } \\
\text { Pearce \& } \\
\text { Conger, 2003; } \\
\text { Pearce \& Manz, } \\
2005\end{array}$} & \multirow{5}{*}{$\begin{array}{l}\text { A non-traditional, self-leading leadership } \\
\text { notion emphasizes on a simultaneous, } \\
\text { ongoing, mutual influence process within a } \\
\text { team whereas official or unofficial leaders } \\
\text { may emerge. Leadership responsibilities } \\
\text { can be shared by members of a team } \\
\text { where multiple members take on } \\
\text { leadership role to take advantage of each } \\
\text { members' strengths to achieve overall } \\
\text { team goal }\end{array}$} & Avolio et al. (1996) & $\begin{array}{l}\text { Shared leadership to be significantly related to self- } \\
\text { ratings of effectiveness. }\end{array}$ \\
\hline & & & Pearce and Sims (2002) & $\begin{array}{l}\text { Shared leadership in peers explain more variance } \\
\text { in team self-rating, manager ratings, and customer } \\
\text { rating of change management team effectiveness. } \\
\text { Shared leadership is significantly related to team } \\
\text { effectiveness. }\end{array}$ \\
\hline & & & $\begin{array}{l}\text { Hooker \& Csikszentmihalyai (2003), } \\
\text { Shamir \& Lapidot (2003) }\end{array}$ & $\begin{array}{l}\text { Shared leadership is significantly related to the } \\
\text { teams effectiveness. }\end{array}$ \\
\hline & & & $\begin{array}{l}\text { Perry et al. (1999), Carson et al. } \\
\text { (2007), Ensley et al. (2003) }\end{array}$ & $\begin{array}{l}\text { Shared leadership in teams is positively related on } \\
\text { team performance. }\end{array}$ \\
\hline & & & $\begin{array}{l}\text { Ensley, Pearson, \& Pearce (2003), } \\
\text { Ensley, Hmieleski, \& Pearce (2006) }\end{array}$ & $\begin{array}{l}\text { Shared leadership is positively related to new } \\
\text { venture performance (growth). }\end{array}$ \\
\hline \multirow[t]{3}{*}{$\begin{array}{l}\text { Team } \\
\text { leadership }\end{array}$} & \multirow{3}{*}{$\begin{array}{l}\text { Burke et al., } \\
\text { 2006; Day et al., } \\
\text { 2004,2006; } \\
\text { Morgeson etal., } \\
\text { 2010; Tagger \& } \\
\text { Ellis, 2007; } \\
\text { Zaccaro et al., } \\
2001\end{array}$} & \multirow{3}{*}{$\begin{array}{l}\text { A dynamic leadership process toward } \\
\text { team-base approach, as an interacting } \\
\text { and collective team, that are brought } \\
\text { together to achieve a common goal.. Self- } \\
\text { managed work team is an example of } \\
\text { team leadership. Self-managed team } \\
\text { leaders lead without positional authority. } \\
\text { Leadership control and power are de- } \\
\text { emphasized, but are shared among team } \\
\text { members. }\end{array}$} & Burke et al., 2006 & $\begin{array}{l}\text { Team leadership behaviors are related to } \\
\text { perceived team effectiveness, team productivity, } \\
\text { and team performance outcome. }\end{array}$ \\
\hline & & & Tagger \& Ellis (2007) & $\begin{array}{l}\text { Collaboration in team leadership is positively } \\
\text { related to team problem-solving norms that } \\
\text { influence the problem-solving behaviors of team } \\
\text { members. }\end{array}$ \\
\hline & & & Morgeson, DeRue, \& Karam (2010) & $\begin{array}{l}\text { An empirical research of high performing Fortune } \\
500 \text { companies organizing work in teams } \\
\text { demonstrates that shared and distributed } \\
\text { leadership among teams has a profound impact on } \\
\text { performance. }\end{array}$ \\
\hline \multirow[t]{2}{*}{$\begin{array}{l}\text { Collective } \\
\text { leadership }\end{array}$} & \multirow{2}{*}{$\begin{array}{l}\text { Avolio etal., } \\
\text { 2009; Carson et } \\
\text { al.,2007; } \\
\text { Crevani etal., } \\
\text { 2009; Friedrich } \\
\text { etal., 2009; } \\
\text { Hauschildt\& } \\
\text { Kirchmann, } \\
\text { 2001; Uhl-Bien et } \\
\text { al.,2007 }\end{array}$} & \multirow{2}{*}{$\begin{array}{l}\text { A contemporary leadership concept } \\
\text { centers on team autonomy, self- } \\
\text { management, and team empowerment, } \\
\text { involving decision-making and other } \\
\text { influential aspects of leadership at the } \\
\text { team level. It is a dynamic leadership } \\
\text { process in which a defined leaders or set } \\
\text { of leaders selectively utilize skills and } \\
\text { expertise within a network, effectively } \\
\text { distributing leadership role to fit with } \\
\text { context. }\end{array}$} & $\begin{array}{l}\text { Crevani, Lindgren \& Packendorff } \\
(2009)\end{array}$ & $\begin{array}{l}\text { Collective leadership can increase the problem- } \\
\text { solving capacity to handle tasks that require } \\
\text { broader competence while simultaneously reducing } \\
\text { pressure on managerial workload. }\end{array}$ \\
\hline & & & $\begin{array}{l}\text { Hauschildt \& Kirchmann (2001), } \\
\text { Howell \& Boies (2004) }\end{array}$ & $\begin{array}{l}\text { A highlight benefit of and importance of having } \\
\text { multiple leaders is its ability to have a team with } \\
\text { diverse skills and expertise. }\end{array}$ \\
\hline \multirow[t]{6}{*}{$\begin{array}{l}\text { Empowering } \\
\text { leadership }\end{array}$} & \multirow{6}{*}{$\begin{array}{l}\text { Arnold et al., } \\
\text { 2000; Ensley et } \\
\text { al., 2006; Manz, } \\
\text { Pearce, \& Sims, } \\
\text { 2009;Pearce \& } \\
\text { Sims, 2002; } \\
\text { Kirkman \& } \\
\text { Rosen,1999; } \\
\text { Srivastava et al., } \\
\text { 2006; Vecchio et } \\
\text { al., } 2010\end{array}$} & \multirow{6}{*}{$\begin{array}{l}\text { A modern leadership approach that allows } \\
\text { leaders to empower/distribute their } \\
\text { exercised power while letting employees to } \\
\text { develop self-control and to act on their } \\
\text { own. It enables followers to make sense of } \\
\text { environments, make independent } \\
\text { decisions, think and act autonomously } \\
\text { without direct supervision, while taking } \\
\text { responsibility of their own work behaviors. } \\
\text { Leadership behaviors focus on share } \\
\text { power with subordinates. }\end{array}$} & Manz, Pearce, \& Sims (2009) & $\begin{array}{l}\text { Empowering leadership has been linked with } \\
\text { various team outcomes and effectiveness. }\end{array}$ \\
\hline & & & $\begin{array}{l}\text { Ensley et al. (2006), Pearce \& Sims } \\
\text { (2002) }\end{array}$ & $\begin{array}{l}\text { Empowering leadership from top levels positive } \\
\text { related to the development of shared leadership in } \\
\text { teams. }\end{array}$ \\
\hline & & & Arnold et al. (2000) & $\begin{array}{l}\text { Empowering leadership link between empowering } \\
\text { leadership and performance. }\end{array}$ \\
\hline & & & Kirkman \& Rosen (1999) & $\begin{array}{l}\text { Empowering leadership is related to job } \\
\text { performance. }\end{array}$ \\
\hline & & & Vecchio etal. (2010) & $\begin{array}{l}\text { Empowering leadership is associated with higher } \\
\text { employee performance and satisfaction. }\end{array}$ \\
\hline & & & $\begin{array}{l}\text { Carmeli \& Schaubroeck (2006) } \\
\text { Ensley et al. (2005), Morgeson et } \\
\text { al. (2010) Pearce (1997), Pearce \& } \\
\text { Sims (2002), Pearce et al. (2004), } \\
\text { Vecchio etal. (2010) }\end{array}$ & $\begin{array}{l}\text { Empowering leadership is associated with } \\
\text { organizational performance outcomes. }\end{array}$ \\
\hline $\begin{array}{l}\text { Leaderful } \\
\text { practice }\end{array}$ & $\begin{array}{l}\text { Raelin , 2005, } \\
2006\end{array}$ & $\begin{array}{l}\text { An alternative leadership notion focuses } \\
\text { on four Cs of leaderful practice suggesting } \\
\text { that emergent leaders should be } \\
\text { concurrent, collective, collaborative and } \\
\text { compassionate through self-leading and } \\
\text { self-managing works. }\end{array}$ & $\begin{array}{l}\text { N/A - No empirical support, only } \\
\text { theoretical framework }\end{array}$ & $\begin{array}{l}\text { N/A - No empirical support, only theoretical } \\
\text { framework }\end{array}$ \\
\hline
\end{tabular}


According to Avery (2004), Organic leadership refers to 'leaderful' and 'leaderless' organizations. Since tomorrow's Organic organizations are likely to have multiple leaders, organizations can become leaderful. As organizations are moving away from the conventional view of leadership, Raelin (2005) urges that an alternative leadership paradigm is needed as organization become boundaryless with influx of knowledge workforce under virtual, network structure. Otherwise, organizations can embrace substitute for leadership (Kerr \& Jermier, 1978) and become leaderless since no one individual in organizations may be recognized as a leader. Jing and Avery (2008) highlight that Organic organizations have no formal leaders while their interaction can act as a form of leadership, which held together by a shared vision, values and supporting culture. The new trend in leadership has transpired to support mutual sense-making within the group where leaders may emerge rather than be appointed in position power and relied upon self-leading organizational members (Avery, 2004). According to Jing \& Avery (2008), Organic organizations allow members to have freedom in self-managing and self-leading as well as participating in mutual decision-making. Jing and Avery (2008) indicate that the idealized Organic leadership concept differs from the classical, transactional, and visionary leadership paradigm by not depending on any formal organizational leader, but relying on its members' ability to solve problems and make decision in the interests of the organization. In doing so, organizations can enhance the problem-solving capacity to handle tasks that require broader competence while simultaneously reducing pressure on managerial workload (Crevani et al., 2009). Challenging the traditional leadership paradigms, Organic leadership has transformed the notion of traditional understanding about leadership, in terms of control, order and hierarchy towards trust, an acceptance of continual change, chaos and respect for diverse members of the organization (Avery, 2004). The leadership of teams or networks has become essential as organizations are moving toward a sustainable path through the twenty-first century and beyond (Manz et al., 2009).

\section{ORGANIC LEADERSHIP ATTRIBUTES}

Avery (2004) purports thirteen indices to distinguish Organic leadership from the other leadership paradigms. the Organic leadership differs from the other paradigms because of the following distinct characteristics: self-governing team; high followers' knowledge base (knowledge workers); group power via collaboration; high follower power; consensual decision-making; distributed leadership; low on Power Distance Inequality; Uncertainty Avoidance, Individualism and Masculinity; high diversity; adapt to change; high selfaccountability and self-responsibility with commitment; network structure; and, suitable for complex and dynamic context (Avery, 2004). However, shared vision and values, self-leading, self-managing and mutual sense-making can result in more desirable sustainability performance outcomes than those without. These distinguish attributes characterize Organic organizations. Table 2 depicts supporting literature that find these attributes to link with sustainability performance outcome. Each is discussed in details below.

\section{Shared vision and values}

Shared vision and values are core to the Organic leadership paradigm. Shared vision and values permeate the entire culture and at multiple levels in Organic organizations (Avery, 2004). While Kantabutra and Avery (2002) accentuate that a powerful and shared vision provides a sense of organization's direction, strong organizational values are essential since they impart the moral, ethical and normative compass to guide and inspire people on how to achieve vision (Bergsteiner \& Avery, 2007). According to Avery (2004), the source of follower commitment is derived from the shared vision and values embraced by all members in the organization.

Since leadership needs to operate through shared vision and values through multiple levels in the entire organization, sharing of unified vision is crucial under the Organic leadership (Avery, 2004). New generation of organizations built around alliances and networks require strategic visions shaped and shared by multiple parties (Pearce et al., 2009). Chamber et al. (2010) advise that the future of leadership should encompass the importance of visioning among teams in order to provide them with a sense of meaning and purpose about their work. Researchers (Day et al., 2004; Katz \& Kahn, 1978; Marks et al., 2001) support that when team members have shared mission and purpose, they should share team's purpose and goal with high commitment that results in improving team process and performance. Recent research by Pearce \& Ensley (2004) emphasizes that vision developed collectively through shared leadership can have a powerful influence on many team dynamics and team performance. In the literature, leadership scholars (Bass, 1985; House \& Aditya, 1997; Kantabutra, 2009; Kantabutra \& Avery, 2005; Reardon, 1991; Senge, 1990) assert that a shared vision between leader and follower is a key to high performance. 
Empirical findings (Kantabutra, 2006, 2008; Kantabutra \& Avery, 2005, 2007, 2009) also lead to the prediction that shared vision enhances both customer and staff satisfaction through emotionally committed followers. Researches (Kantabutra 2006, 2008, 2009; Kantabutra \& Avery, 2002, 2005, 2007, 2009) further endorse that an effective vision can result in better business performance.

Besides shared vision, shared values of members in organizations are principal under the Organic leadership. Values are the 'soft rules' of an organization that affect organizational behavior (Schnebel, 2000). While shared values fortify an organizational culture (Bergsteiner \& Avery, 2007), they affect work attitudes and performance through enhancing personal effectiveness, company loyalty, ethical behaviors, hard working, caring and fostering teamwork (Sarros, Butchatsky \& Santora, 1996). Based on Avery \& Bergsteiner's (2010) Honeybee practice, shared values enable a strong culture. Researches (Balthazard, Cooke \& Potter, 2006; Marcoulides \& Heck, 1993) also support that shared values are associated with enhanced organizational performance. For example, according to Yaniv \& Farkas (2005), aligning staff with organizational values can positively affect customer perceptions of the brand.

Moreover, high self-accountability, self-responsibility and adaptability are key shared values that enable mutual commitment among Organic organizational members. According to Bergsteiner \& Avery (2007), high accountability is shared among peers, stemming from their mutual commitments under the Organic leadership culture. Avery (2004) suggests that Organic organizations should be constantly prepared for change and continuously adapted to change under the more chaotic, ever-changing environment. A mutual commitment among peers also enhances accountability and responsibilities among individuals in organizations (Bergsteiner \& Avery, 2007). Overall, both shared, sustainable visions and shared values fasten the internetworked organizations of Organic leadership together. According to Jing and Avery (2008), future studies on leadership and performance relationship should adopt vision sharing as a mediator. As such, in our proposed research model, shared vision and values is the mediator between the Organic leadership and sustainability performance outcome.

\section{Self-leading}

While the classical, transactional and visionary leadership paradigms emphasize one single heroic leader approach, the Organic leadership paradigm features multiple players with many leaders or no leaders (Avery, 2004). Today's leadership is distributed across organizations. Given the dynamic environmental changes surrounding organizations, the recent trend has shifted from the leader-centered approach toward self-leading organizations with no formal authority. Organizational operations now focus on self-leading workers (Manz, 1990). Avery (2004) highlights that Organic organizations heavily rely on self-leading members where self-leadership is regard as a form of leader substitute. Leadership may emerge from any members or multiple members of organizations for strategic decisions or changes in direction (Raelin, 2005). Pearce et al. (2008) asserts that having a formal leader to lead from geographically dispersed locations would be impossible, but instead leadership and responsibilities should be shared by organizational members. Self-leaders seek to influence the overall purpose behind the system, thereby serving higher-level organizational goals. Influences from followers in leading teams offer potential to create a sustainable, effective and flexible leadership infrastructure (Manz et al., 2009).

Today's trend toward highly dispersed organization, distributed teams and remote, global workers have made it difficult for a single leader to retain control and exercise legitimate power (Avery, 2004). Given the decentralization of power, employees in the Organic organization are empowered. Several researchers (Conger \& Kanungo, 1988; Manz, 1990; Manz \& Sims, 1991; Perce \& Sims, 2002; Pearce \& Conger, 2003; Offermann, 2010) advocate that empowerment is an essential element for modern organizations. Self-leading organizations requires employees to be empowered and to align with an organization's culture and values. The success of self-leading team depends on empowerment in which members require very little external leadership. In leading organizations, leaders can help others to lead themselves by acting as teach or coach, not as director as in the traditional leadership paradigms (Avery, 2004). These self-leading members or teams are generally well-educated, knowledge workforce which is more competent, more independent and more intrinsically motivated than workers of the previous era; they are capable of leading changes (Raelin, 2005). Empirically, self-leading organizations are related to enhanced performance outcomes. According to researches (eg. Manz, 1986, 1990; Manz \& Neck, 1997), self-leadership in empowering organization is considered pivotal to employee's commitment toward performance. A recent study by Friedrich et al. (2009) identifies an important relationship between networks of leaders and team performance. 


\section{Self-managing}

Under the Organic leadership, members are self-managing. Self-managing is a substitute for leadership (Manz \& Sims, 1991). Leadership can change depending on the most appropriate member for a given time and context (Avery, 2004). Under the Organic leadership paradigm, leadership is not viewed as a position or authority based on the top-down hierarchical structure, but as an emergent interactive dynamic system where multiple individuals interact together (Avery, 2004; Plowman et al., 2007; Chambers et al., 2010). In the knowledge-based economy, two keys to achieve organizational sustainability are teamwork and collaboration (Power \& Waddell 2004; Avery \& Bergsteiner, 2010). Today's organizations are transforming themselves into networked structures with focused on team-based system. Barry (1991) asserts that team-based leadership is suitable for organizations with reliance on self-managing teams (SMTs), particularly project-based work or consulting projects. Relationships among team members to enhance cooperation and resource exchange become essential as leadership is a property of the team, rather than an individual (Zander \& Butler, 2010). Under self-managing organizations, leaders trust members' capacity to solve problems and make decisions in the interest of the organization, where the movement of self-control and self-organization emerge (Avery, 2004). Under the self-control and self-organization, people have a clear sense of purpose and autonomy within a particular context (Meindl, 1998). Howell et al. (1990) indicate that highly-trained knowledge workers can usually perform several tasks without supervision while having a desire for the autonomous, self-controlling behavior appropriate to the Organic paradigm. According to Manz \& Neck (1997), self-managing teams have been positively linked with increased quality, productivity, employee quality of work life and decreases in absenteeism and turnover.

Organic organizations tend to enable employees at all levels to exercise judgment on various issues, and require their participation in decision making (Avery, 2004). Consensus and mutual decision-making promotes voluntary and deeper commitment and greater understanding of a challenge or goal (Locke \& Latham, 1990). In modern organizations, team decision-making with consensus is a highly preferable approach (Pearce et al., 2008) where decision-making authority is shared across team members (Carson et al., 2007). Consistent with Organic organizations, organizations perusing Avery and Bergsteiner (2010)'s Honeybee leadership focusing on strong participative, devolved decision-making and empowerment in various levels of organization enable organizational sustainability through innovations that are created within organizations.

Overall, a key to sustainable enterprises and their success of self-managing and self-governing working team relies on competent staff who share leadership responsibilities and collaboration; moreover, sharing work in teams and workshops yields great advantages as it enhances employee power, increase expertise from multi-skilling and personal effectiveness through enhanced communication (Avery, 2004). A study by Carmeli and Schaubroeck (2006) also reveals that information exchange, collaboration, and joint-decision making are related to positive organizational outcomes. According to Avery \& Bergsteiner (2010), self-management decreases the need for unnecessary supervisors, directly affects enhanced financial performance and long-term shareholder value, and indirectly affects enhanced brand and reputation and customer satisfaction.

\section{Mutual sense-making}

Given the increasing complexity and uncertainty in the business environment, complexity science (UhlBien et al., 2007) suggests a shift in leadership paradigm. Today's modern organizations encourage multi-directional influence from workers with knowledge, skills and abilities from various organizational levels to benefit organizational effectiveness and member self-efficacy (Pearce et al., 2008). Capable leaders depend on expertise of their knowledge workers (Pearce \& Conger, 2003). The ability of knowledge workers to search for and utilize information, learn new skills and feel comfortable in ambiguous work situations has become crucial (Abell, 2000). According to Avery (2004), in the fast-changing, ambiguous and chaotic environment, there is no one right answer, but the entire group needs to go through the sense-making process by searching for the meanings of changes around them. Mutual sense-making is thus imperative for modern organizations (Weick, 1995). Avery (2004) asserts that Organic organizations need diverse expertise of knowledge workers to be able to effectively respond to dynamic, knowledge-based environment and indeed enables effective mutual sense-making among organizational members. Friedrich et al. (2009) further suggest that an essence of having diversity of expertise among team members enhances collaboration and information-sharing to find "right" answers to what make sense in various contexts and thus yielding benefits to organizational performance. 
Mutual sense-making is indeed an enabling leadership capability for future organizations as multiple members of organization seek various types and sources of data while involving others in the process to make sense of things around them (Chamber et al., 2010). And, through extensive communication and information-sharing, the sense-making process can help members in organizations to share, interpret and interconnect what necessary to achieve organizational goals. Avery (2004) asserts that members make sense of fast-changing circumstances through extensive communication process; communication and information-sharing among team members help to make sense of changes in their environment. Sense-making can enhance knowledge creation since people within organizations interact and share individual interpretations of knowledge, reality and experiences to construct meaning (Choo, 1996). According to Choo (1996, p.338), "sense-making supplies a meaningful context for all organizational activity and in particular guides the knowledge creation process." Under the Organic leadership, employee power is overall high through mutual sense-making members who influence the organization's direction. According to Avery (2004), employees under the Organic leadership become interacting partners in determining what makes sense, how to adapt to change and what is a useful direction. Research indicates that strategic sensemaking is positively linked with organizational performance (Thomas, Clark \& Gioia, 1993).

Table 2: Literature linking attributes of Organic organizations with performance outcomes.

\begin{tabular}{|c|c|c|c|}
\hline Research & Description of study & Independent variable & Dependent variable \\
\hline Pearce \& Ensley (2004) & $\begin{array}{l}\text { A vision developed collectively through shared leadership can } \\
\text { have a powerful influence on many team dynamics and team } \\
\text { performance. }\end{array}$ & $\begin{array}{l}\text { a collective (shared) } \\
\text { vision }\end{array}$ & $\begin{array}{l}\text { team effectiveness, } \\
\text { team performance }\end{array}$ \\
\hline $\begin{array}{l}\text { Kantabutra }(2006,2007,2008 \\
2009) ; \text { Kantabutra \& Avery }(2004 \\
2005,2006,2007)\end{array}$ & $\begin{array}{l}\text { An effective, impactful good vision can create a positive impact on } \\
\text { organizational performance through emotionally committed } \\
\text { followers. }\end{array}$ & $\begin{array}{l}\text { an effective, impactful } \\
\text { good vision }\end{array}$ & $\begin{array}{l}\text { organizational } \\
\text { performance }\end{array}$ \\
\hline $\begin{array}{l}\text { Bass (1985); House \& Aditya } \\
\text { (1997) Howell \& Shamir, (2005); } \\
\text { Kantabutra \& Avery (2006); } \\
\text { Reardon (1991); }\end{array}$ & $\begin{array}{l}\text { A shared vision between leader and follower is a key to high } \\
\text { performance. }\end{array}$ & a shared vision & performance. \\
\hline $\begin{array}{l}\text { Sarros, Butchatsky \& Santora, } \\
1996\end{array}$ & $\begin{array}{l}\text { Shared values affect work attitudes and performance through } \\
\text { enhancing personal effectives, company loyalty, ethical behaviors, } \\
\text { working hard, caring and fostering teamwork }\end{array}$ & shared values & $\begin{array}{l}\text { teamwork, } \\
\text { performance }\end{array}$ \\
\hline Yaniv \& Farkas (2005) & $\begin{array}{l}\text { Aligning (shared) values between staff and organizational values } \\
\text { can positively affect customer perceptions of the brand }\end{array}$ & $\begin{array}{l}\text { (shared) Organizational } \\
\text { values }\end{array}$ & brand and reputation \\
\hline Avery \& Bergsteiner(2010) & $\begin{array}{l}\text { Shared vision and values can lead to exceed customer } \\
\text { expectations and satisfaction }\end{array}$ & shared vision and values & customer satisfaction \\
\hline $\begin{array}{l}\text { Balthazard, Cooke \& Potter, 2006; } \\
\text { Marcoulides \& Heck, 1993) }\end{array}$ & $\begin{array}{l}\text { Culture (including values) is associated with enhanced } \\
\text { organizational performance }\end{array}$ & culture (including values) & $\begin{array}{l}\text { organizational } \\
\text { performance }\end{array}$ \\
\hline Manz (1990) & $\begin{array}{l}\text { Self-leadership in empowering organization is considered pivotal } \\
\text { to employee's commitment toward performance }\end{array}$ & self-leadership & performance \\
\hline Friedrich et al. (2009) & $\begin{array}{l}\text { Relationship among networks of leaders and team affects } \\
\text { organizational performance }\end{array}$ & $\begin{array}{l}\text { (self-leading) networks of } \\
\text { leaders and team }\end{array}$ & $\begin{array}{l}\text { organizational } \\
\text { performance }\end{array}$ \\
\hline Morgeson et al. (2010) & $\begin{array}{l}\text { High performing Fortune } 500 \text { companies organizing work in teams } \\
\text { demonstrates that shared, distributed leadership has a profound } \\
\text { impact on performance }\end{array}$ & $\begin{array}{l}\text { (Self-leading) shared, } \\
\text { distributed leadership }\end{array}$ & performance \\
\hline Carmeli \& Schaubroeck (2006) & $\begin{array}{l}\text { The empirical research signifies information exchange, } \\
\text { collaboration, and joint-decision making, underlying self- } \\
\text { managing, are related to positive organizational outcomes }\end{array}$ & $\begin{array}{l}\text { (Self-managing) } \\
\text { information exchange, } \\
\text { collaboration, and joint- } \\
\text { decision }\end{array}$ & $\begin{array}{l}\text { organizational } \\
\text { outcomes }\end{array}$ \\
\hline \multirow[t]{2}{*}{ Avery \& Bergsteiner (2010) } & $\begin{array}{l}\text { Self-management decreases the need for unnecessary } \\
\text { supervisors, it directly affects financial performance and long-term } \\
\text { shareholder value, and indirectly affects brand and reputation and } \\
\text { customer satisfaction. }\end{array}$ & $\begin{array}{l}\text { self-management (self- } \\
\text { managing) }\end{array}$ & $\begin{array}{l}\text { financial performance, } \\
\text { long-term shareholder } \\
\text { value }\end{array}$ \\
\hline & & $\begin{array}{l}\text { self-management } \\
\text { (self-managing) }\end{array}$ & $\begin{array}{l}\text { brand and reputation } \\
\text { and customer } \\
\text { satisfaction. }\end{array}$ \\
\hline Friendrich et al. (2009) & $\begin{array}{l}\text { The essence of having diversity in team expertise to collaborate } \\
\text { and share inf ormation toward sense-making yields benefit } \\
\text { organizational performance. }\end{array}$ & sense-making & $\begin{array}{l}\text { organizational } \\
\text { performance. }\end{array}$ \\
\hline Thomas, Clark \& Gioia (1993) & $\begin{array}{l}\text { Strategic sense-making is positively linked with organizational } \\
\text { performance. }\end{array}$ & sense-making & $\begin{array}{l}\text { organizational } \\
\text { performance. }\end{array}$ \\
\hline
\end{tabular}




\section{SUSTAINABILITY PERFORMANCE OUTCOMES}

Researchers have long examined the relationship between leadership and performance outcome. Numerous leadership scholars (Avery, 2004; Bennis \& Nanus, 1985; Drath, 2001; House \& Aditya, 1997; Jing \& Avery, 2008; Avery \& Bergsteiner, 2010; Yulk, 1998, 2006) have critically examined the effectiveness of leadership behaviors on organizational performance. In the literature, leadership is viewed as one of the key driving forces for improving a firm's performance. For decades, leadership studies have mainly focused on identifying and assessing leaders that improve organizational performance in the traditional paradigms. Very little research has been done into a relationship between the Organic leadership and performance outcomes. Even scantier is research into the relationship between the Organic leadership and sustainability performance outcomes. According to Vecchio et al. (2010), whether team-based, process-based leadership, underlying the Organic leadership, is demonstrably related to superior performance outcomes is still relatively unknown.

In terms of sustainability performance outcomes, leadership scholars (Epstein \& Roy, 2001; Kantabutra, 2006; Jing \& Avery, 2008) have been searching for ways to measure them. Jing \& Avery (2008) suggest that scholars need to examine multiple performance measures both financial measurements and non-financial measurements to ensure robust results of leadership-performance studies and enhance validity of the research. To measure impact on business performance and its sustainability, Kantabutra (2006) proposes three key measures, including employee satisfaction, customer satisfaction and financial outcomes. Avery and Bergsteiner (2010, p. 181) emphasize that "To be sustainable also requires enhancing customer satisfaction, brand and reputation and long-term stakeholder value." In their recent study, Avery and Bergsteiner (2010) propose that sustainable leadership can lead to four sustainability performance outcomes: (1) financial performance, (2) shareholder value, (3) customer satisfaction and (4) brand and reputation. These four sustainability performance outcomes are comprehensive; and thus they are adopted for our research model.

Much empirical research (e.g. George, 1990; Schmitt \& Allscheid, 1995; Ulrich et al., 1991; Wiley, 1991) demonstrates a strong positive relationship between leadership styles, employee and customer satisfaction, and organizational performance. Jing and Avery (2008) indicate that previous research has hypothesized that leadership paradigms would have effects on customer satisfaction, staff satisfaction and financial performance since positive changes in employee satisfaction and customer satisfaction can lead to positive changes in organizational performance. Although the literature suggests that a relationship between leadership and corporate sustainability exists, a relationship between the Organic leadership attributes and sustainability performance outcomes are not yet known. Thus, a research model is proposed next.

\section{STRUCTURAL MODEL AND HYPOTHESES}

Derived from the literature, a model expressing the relationships between Organic leadership characteristics and sustainability performance outcomes is proposed, followed by relevant hypotheses.

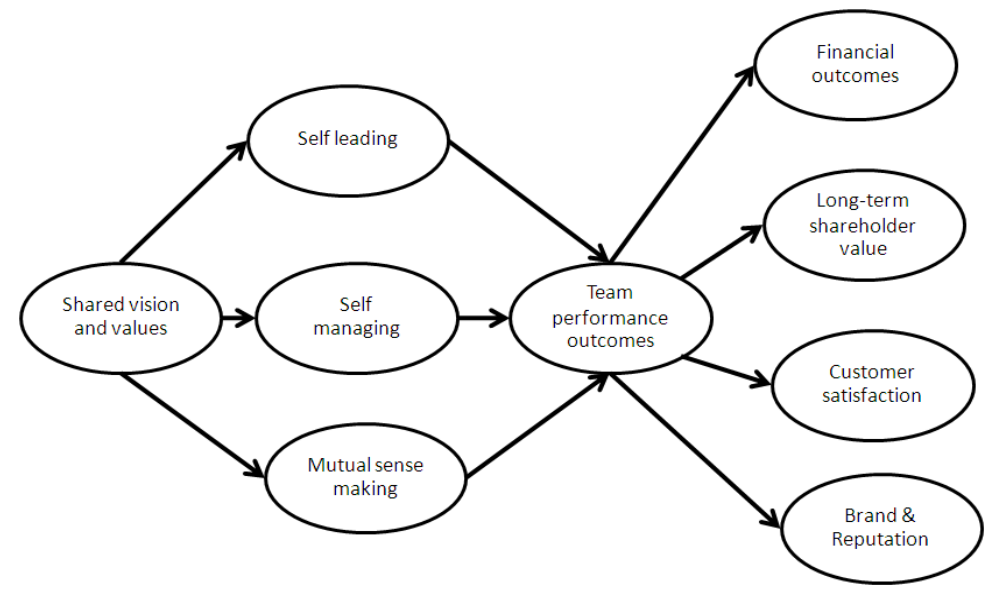

Figure 1. Structural model linking Organic leadership characteristics to sustainability performance outcomes 
Based on the proposed model, directional hypotheses are developed as follow:

H1. Shared vision and values is indirectly predictive of enhanced financial performance.

H2. Shared vision and values is indirectly predictive of enhanced long-term shareholder value.

H3. Shared vision and values is indirectly predictive of enhanced customer satisfaction.

H4. Shared vision and values is indirectly predictive of enhanced brand and reputation.

H5. Shared vision and values is directly predictive of enhanced self-leading.

H6. Self-leading is directly predictive of enhanced team performance outcomes.

H7. Shared vision and values is directly predictive of enhanced self-managing.

H8. Self-managing is directly predictive of enhanced team performance outcomes.

H9. Shared vision and values is directly predictive of enhanced mutual sense-making.

H10. Mutual sense-making is directly predictive of enhanced team performance outcomes.

H11. Team performance outcomes is directly predictive of enhanced financial performance.

H12. Team performance outcomes is directly predictive of enhanced long-term shareholder value.

H13. Team performance outcomes is directly predictive of enhanced customer satisfaction.

H14. Team performance outcomes is directly predictive of brand and reputation.

\section{FUTURE RESEARCH DIRECTIONS}

Clearly, future research is needed to test the 14 hypotheses. One critical area to test is whether the Organic leadership characteristics, including shared vision and values, self-leading, self-managing and mutual sense-making are associated, via team performance outcomes, with improved sustainability performance outcomes: financial performance, long-term shareholder value, customer satisfaction, and brand and reputation. Managerial implications of the findings will be important for corporate leaders to ensure their long-term organizational success.

\section{AUTHOR INFORMATION}

Associate Professor Sooksan Kantabutra is Chief Researcher of Leadership Research Group, College of Management, Mahidol University in Bangkok since 2003. He holds a BA from Chiang Mai University, an MBA from Bentley University, Boston, USA and an MA and a PhD in management from Macquarie University in Sydney, Australia. Prior to joining Mahidol University, Sooksan Kantabutra worked for a global consulting firm where he advised multinational corporations on leadership and change. He currently specializes in leadership and develops senior executive leadership programs for well-known organizations based in Asia. He can be reached at cmsooksan@mahidol.ac.th.

Suparak Suriyankietkaew is a PhD candidate at College of Management, Mahidol University in Bangkok and Graduate School of Management, Macquarie University in Sydney. A Royal Golden Jubilee PhD scholar of Thailand Research Fund, Suparak holds a BSc and an MSc from University of Maryland, USA. Her research has focused on leadership and corporate sustainability. She has a number of years working with multinational corporations and has been an adjunct lecturer at Bangkok University. She can be reached at ssuparak@gmail.com. Corresponding author.

\section{REFERENCE}

1. Abell, A. (2000). Skills for knowledge environments. Information Management Journal, 34(3), 33-41.

2. Arnold, J., Arad, S., Rhoades, J., \& Drasgow, F. (2000). The empowering leadership questionnaire: The construction and validation of a new scale for measuring leader behaviors. Journal of Organizational Behavior, 21, 249-269.

3. Arnone, M., \& Stumpf, S. (2010). Shared leadership: from rivals to co-CEOs. Strategy \& Leadership, $38(2), 15-21$.

4. $\quad$ Avery, G. C. (2004). Understanding Leadership .London: Sage Publications Ltd.

5. Avery, G.C., \& Bergsteiner, H. (2010). Honeybees \& Locusts: The Business Case for Sustainable

Leadership. NSW: Allen \& Unwin. 
6. Avolio, B.J., Jung, D., Murry, W., \& Sivasubramaniam, N. (1996). Building highly developed teams: Focusing on shared leadership process, efficacy, trust, and performance. In D.A. Beyerlein, D.A. Johnson, \& S.T. Beyerlein (Eds.). Advanced in interdisciplinary studies of work teams (pp. 173-209). Greenwich, CT: JAI Press.

7. Avolio, B.J., Walumbwa, F.O., \& Weber, T.J. (2009). Leadership current theories, research and future directions. Annual review of Psychology, 60, 421-449.

8. Balthazard, P.A., Cooke, R.A., \& Potter, R.E. (2006). Dysfunctional organization: Capturing the behavioral norms that form organizational culture and drive performance. Journal of Managerial Psychology, 21(8), 709-732.

9. Barry, D. (1991). Managing the Bossless Team: Lessons in Distributed Leadership. Organizational Dynamics, 20(1), 31-47.

10. Bass, B.M. (1985) Leadership \& Performance Beyond Expectations. New York, NY: Free Press.

11. Bennis, W. \& Nanus, B. (2003). Leaders: The Strategies for Taking Charge (2 ${ }^{\text {nd }}$ ed.). New York, NY: Harper and Row.

12. Bergsteiner, H., \& Avery, C.G. (2007). Adapting Accountability Responses to Leadership Context. The International Journal of Interdisciplinary Social Sciences, 2(2): 411-420.

13. Brown, M.E., \& Gioia, D.A. (2002). Making things click: Distributive leadership in an online division of on offline organization. The Leadership Quarterly, 13, 397-419.

14. Burke, C.S., Stagl, K.C., Klein, C., Goodwin, G.F., Salas, E., \& Halpin, S.M. (2006). What type of leadership behaviors are functional in teams?: A meta-analysis. The Leadership Quarterly, 17, 288-307.

15. Carmeli, A., \& Schaubroeck, J. (2006). Top management team behavioral integration, decision quality, and organizational decline. The Leadership Quarterly, 17, 441-453.

16. Carson, J.B., Tesluk, P.E., Y Marrone, J.A. (2007). Shared leadership in teams. An investigation of antecendent conditions and performance. Academy of Management Journal, 50(5), 1217-1234.

17. Chambers, L., Drysdale, J., \& Hughes, J. (2010). The future of leadership: A practitioner view. European Management Journal, 28(4), 260-268.

18. Choo, C.W. (1996). The Knowing Organization: How Organizations Use Information to Construct Meaning, Create Knowledge, and Make Decisions, International Journal of Information Management, 16, 329-340.

19. Conger, J.A., \& Kanungo, R.N. (1998). The Empowerment process: Integrating theory and practice. Academy of Management Review, 13, 639-652.

20. Crevani, L., Lindgren, M. \& Packendorff, J. (2009). Leadership, not leaders: On the study of leadership as practices and interaction. Scandinavian Journal of Management, 26(1), 77-86.

21. Day, D.V., Gronn, P., \& Salas, E. (2004). Leadership capacity in teams. The Leadership Quarterly, 15, 857-880.

22. Day, D.V., Gronn, P., \& Salas, E. (2006). Leadership in team-based organizations: On the threshold of a new era. The Leadership Quarterly, 17, 211-216.

23. DeChurch, L.A., Hiller, N.J., Murase, T., Doty, D., \& Salas, E. (2010). Leadership across levels: Level of leaders and their levels of impact. The Leadership Quarterly, 21, 1069-1085.

24. Ensley, M.D. \& Pearce, C.L., (2001). Shared cognition as a process and an outcome in top management teams: implications for new venture performance. Journal of Organizational Behavior, 22, 145-160.

25. Ensley, M.D., Hmieleski, K.M., \& Pearce, C.L., (2006). The importance of vertical and shared leadership within new venture top management teams: Implications for the performance of startups. The Leadership Quarterly, 17, 217-231.

26. Epstein, M. J., \& Roy, M. J. (2001). Sustainability in Action: Identifying and Measuring the Key Performance Drivers. Long Range Planning Journal, 34, 585-604.

27. Fletcher, J.K., \& Kaufer, K. (2003). Shared leadership. In C.L. Pearce \& J.A. Conger (Eds.), Shared leadership: Reframing the hows and whys of leadership. Thousand Oaks, California: Sage.

28. Friedrich, T.L., Vessey, W.B., Schuelke, M.J., Ruark, G.A., \& Mumford, M.D. (2009). A framework for understanding collective leadership: The selective utilization of leader and team expertise within networks. The Leadership Quarterly, 20, 933-958.

29. Gardner, W.L., Lowe, K.B., Moss, T.W., Mahoney, K.T., Cogliser, C.C. (2010). Scholarly leadership of the study of leadership: A review of The Leadership Quarterly's second decade, 2000-2009. The Leadership Quarterly, 21(6), 922-958. 
30. George, W.R. (1990). Internal marketing \& organizational behavior: A partnership in developing customerconscious employees at every level. Journal of Business Research, 20 (1), 63-70.

31. Gronn, P. (2002). Distributed leadership as a unit of analysis. The Leadership Quarterly, 13, $423-451$.

32. Hauschildt, J., \& Kirchmann, E. (2001). Teamwork for innovation-The Trioka of promoters. $R \& D$ Management, 31, 441-444.

33. Hiller, N.J., Day, D.V. ,\& Vance, R.J. (2006). Collective enactment of leadership roles and team effectiveness: A field study. The Leadership Quarterly, 17, 387-397.

34. Hooker, C., \& Csikezentmihalyai, C. (2003). Flow, creativity and shared leadership: Rethinking the motivation and structuring of knowledge work. In C.L. Pearce, \& J.A. Conger (Eds.). Shared leadership: Reframing the hows and whys of leadership. Thousand Oaks, CA: Sage.

35. House, R.J. ,\& Aditya, R.N. (1997). "The social scientific study of leadership: Quo Vadis?” Journal of Management, 23(3): 409-473.

36. Howell, J.P., Bowen, D.E., Dorfman, P.W., Kerr, S. and Podsakoff, P.M. (1990), 'Substitutes for leadership: Effective alternatives to ineffective leadership', Organizational dynamics, 19(1): 21-38.

37. Jing, F. \& Avery, G. (2008). "Missing Links in Understanding The Relationship between Leadership And Organizational Performance.” International Business \& Economics research Journal, 7(5): 67-78.

38. Judge, T.A., Heller, D., \& Mount, M.K. (2002). Five-factor model of personality \& job satisfaction: A meta-analysis. Journal of Applied Psychology, 87(3): 530-541.

39. Judge, T.A. \& Piccolo, R.F. (2004). Transformational \& transactional leadership: A meta-analytic test of their relative validity. Journal of Applied Psychology, 89(5): 755-768.

40. Kantabutra, S. (2006). Relating vision-based leadership to sustainable business performance: A Thai perspective. Kravis Leadership Institute Leadership Review. 6(Spring): 37-53

41. Kantabutra, S. (2008). Vision effects in Thai retail stores: practical implications. International Journal of Retail \& Distribution Management, 36(4), 323-342

42. Kantabutra, S. (2009). Toward a behavioral theory of vision in organizational settings. Leadership \& Organization Development Journal, 30(4), 319-337.

43. Kantabutra, S. \& Avery, G.C. (2002) Proposed model for investigating relationships between vision components and business unit performance. Journal of Management and Organization, 8(2), 22-39

44. Kantabutra, S., \& Avery, G.C. (2005). Essence of shared vision: Empirical investigation. New Zealand Journal of Human Resources Management, 5, 1-28.

45. Kantabutra, S., \& Avery, G.C. (2007). Vision effects in customer and staff satisfaction: Empirical investigations. Leadership and Organization Development Journal, 28(3), 209-229.

46. Kantabutra, S., \& Avery, G.C. (2009). Shared vision in customer and staff satisfaction: Relationship and their consequences. Journal of Applied Business Research, 25(4), 9-22.

47. Kerr, S., \& Jermier, J.M. (1978). Substitutes for leadership: their meaning and measurement. Organizational Behavior and Human Performance, 22, 375-403.

48. Kirkman, B.L., \& Rosen, B. (1999). Beyond self-management: Antecedents and consequences of team empowerment. Academy of Management Journal, 42, 58-74.

49. Locke, E. A., \& Latham, G.P. (1990). A theory of goal setting and task performance. Englewood Cliffs, NJ: Prentice Hall.

50. Manville, B., \& Ober, J. (2003). Beyond empowerment: Building a company of citizens. Harvard Business Review, 48-53.

51. Manz, C.C. (1990). 'Self-leading work teams: Toward self-leading teams in the workplace' in R. Woodman and W. Pasmore (eds). Research in Organizational Change and Development. Greenwich, CN: JAI Press.

52. Manz, C.C. \& Neck, C.P. (1997), Teamthink: beyond the groupthink syndrome in self-managing work teams. Team performance management, 3(1), 18-31.

53. Manz, C.C., \& Sims, H.P., Jr. (1991). Superleadership: Beyond the myth of heroic leadership. Organizational Dynamics, 19(4), $18 \mathrm{ff}$.

54. Manz, C.C., Pearce, C.L., \& Sims, H.P., Jr. (2009). The Ins and Outs of Leading Teams: An Overview. Organizational Dynamics, 38(3), 179-182.

55. Marcoulides, G.A., \& Heck, R.H. (1993). Organizational culture and performance: Proposing and testing a model. Organization Science, 4(2), 209-925.

56. Marion, R., \& Uhl-Bien, M. (2007). Introduction to the special issue on leadership and complexity. The Leadership Quarterly, 18, 293-296. 
57. McGrath, G.R., \& MacMillan, I.C. (2000). Entrepreneurial Mindset: Strategies for Continuously Crating Opportunity in an Age of Uncertainty. Harvard Business School Press Books.

58. Mehra, A., Smith, B.R., Dixon, A.L., Robertons, B. (2006). Distributed leadership in teams: The network of leadership perceptions and team performance. The Leadership Quarterly, 17, 232-245.

59. Meindl, J.R. (1998). Invited reaction: Enabling visionary leadership. Human Resource Development Quarterly, 9(1), 21-24.

60. Meyer, G.D., \& Heppard, K.A. (2000). Entrepreneurial Strategies: The Dominant Logic of Entrepreneurship. New York, NY: Irwin University Books.

61. Morgeson, F.P., DeRue, S.D., \& Karam, E.P. (2010). Leadership in teams: A functional approach to understanding leadership structures and processes. Journal of Management, 36(1), 5-39.

62. Offermann, L. (2010). Empowerment. Leading Organizations: Perspectives for a new era $\left(2^{\text {nd }}\right)$. Thousand Oaks, CA: SAGE.

63. Pearce, C.L., \& Conger, J.A. (2003). All those years ago: The historical underpinnings of shared leadership. In C.L. Pearce, \& J.A. Conger (Eds.), Shared leadership: Reframing the hows and whys of leadership (p. 1-18). Thousand Oaks, CA: Sage.

64. Pearce, C.L., \& Ensley, M.D. (2004). A reciprocal and longitudinal investigation of the innovation process: the central role of shared vision in product and process innovation teams (PPITs). Journal of Organizational Behavior, 25(2), 259-278.

65. Pearce, C.L., \& Sims, H.P., Jr. (2002). Vertical versus shared leadership as predictors of the effectiveness of change management teams: an examination of aversive, directive, transactional, transformational, and empowering leader behaviors. Group Dynamics, Theory, Research and Practice, 6(2), 172-197.

66. Pearce, C. L., Conger, J.A \& Locke, E.A. (2008). Shared leadership theory. The Leadership Quarterly, 19: 622-628

67. Pearce, C.L., Manz, C.C., \& Sims, H.P., Jr. (2009). Where do we go from here? Is shared leadership the key to team success? Organizational Dynamics, 38(3), 234-238.

68. Pettigrew, A.M., Ferlie, E.F. \& McKee, L. (1992). Shaping strategic change. London: Sage.

69. Power, J. and Waddell, D. (2004) The link between self-managed work teams and learning organizations using performance indicators. Learning Organization, 11(3), 244-59.

70. Plowman, D. A., Solansky, S., Beck, T.E., Baker, L, Kulkarni, M., \& Travis, D.V. (2007). The role of leadership in emergent, self-organization. The Leadership Quarterly, 18, 341-356.

71. Purcell, J., Kinnie, N., Hutchinson, S.Rayton, B., \& Swart, J. (2004). Understanding the People \& Performance Link: Unlocking the Black Box. Research Report, Chartered Institute of Personnel and Development.

72. Raelin, J.A. (2005). We the Leaders: In Order to Form a Leaderful Organization. Journal of Leadership and Organizational Studies, 12(2), 18-30.

73. Raelin, J.A. (2006). Does action learning promote collaborative leadership? Academy of Management Learning \& Education, 5(2), 152-168.

74. Sarros, J.C., Butchatsky, O., \& Santora, J.C.(1996). Breakthrough leadership: Leadership skills for the twenty-first century. In K.W.Parry (Ed.). Leadership research and practice: Emerging themes and new challenges (p.41-52). Melbourne: Pitman.

75. Schmitt, M.J., \& Allscheid, S.P. (1995). Employee attitudes \& customer satisfaction: Making a theoretical \& empirical connection. Personnel Psychology, 48, 521-537.

76. Schneider, M., \& Somers, M. (2006). Organizations as complex adaptive systems: Implications of complexity theory for leadership research. The Leadership Quarterly, 17(4), 351-365.

77. Shamir, B., \& Lapidot, Y. (2003). Shared leadership in the management of group boundaries: A study of expulsions from officers' training courses. In C.L. Pearce, \& J.A. Conger (Eds.). Shared leadership: Reframing the hows and why of leadership. Thousand Oaks, CA: Sage.

78. Snow, C.C., \& Miles, R.E. (1992). Managing $21^{\text {st }}$ century network organizations. Organizational Dynamics, 20(3), 5-19.

79. Srivastava, A., Bartol, K.M., \& Locke, E.A. (2006). Empowering leadership in management teams: Effects on knowledge sharing, efficacy, and performance. Academy of Management Journal, 49, 1239-1251.

80. Tagger, S., \& Ellis, R. (2007). The role of leaders in shaping formal team norms. The Leadership Quarterly, 18, 105-120. 
81. Thomas, J.B., Clark, S.M. and Gioia, D.A. (1993). Strategic sense-making and organizational performance: linkages among scanning, interpretation, action and outcomes. Academy of Management Journal, 36(2), 239-270.

82. Uhl-Bien, M., Marion, R., \& McKelvey, B. (2007). Complexity leadership theory: Shifting leadership from the industrial age to the knowledge era. The Leadership Quarterly, 18, 298-318.

83. Ulrich,D., Halbrook, R., Meder, D., Stuchlik, M., \& Thorpe, S. (1991). Employee \& customer attachment: Synergies for competitive advantage. Human Resource Planning, 14, 89-103.

84. Vecchio, R.P, Justin, J.E., \& Pearce, C.L. (2010). Empowering leadership: An examination of mediating mechanisms within a hierarchical structure. The Leadership Quarterly, 21, 530-542.

85. Weick, K.E. (1995). Sense-making in Organizations. Thousand Oaks, CA: Sage.

86. Wiley, J.W. (1991). Customer satisfaction: A supportive work environment \& its financial cost. Human Resource Planning, 14, 117-127.

87. Yaniv, E.,\& Farkas, F. (2005). The impact of person-organization fit on the corporate brand perception of employees and of customers. Journal of Change Management, 5(4), 447-61.

88. Yukl, G. (2002). Leadership in Organizations. (5 ${ }^{\text {th }}$ ed.) Englewood Cliffs, NJ: Prentice-Hall.

89. Zaccaro, S.J., Rittman, A.L., \& Marks, M.A. (2001). Team leadership. The Leadership Quarterly, 12, 451483.

90. Zander, L., \& Butler, C.L. (2010). Leadership modes: Success strategies for multicultural team. Scandinavian Journal of Management, 26, 258-267. 
NOTES 